\title{
Imagem e experiência
}

\section{Resumo}

O presente texto considera a capacidade das imagens virtuais repercutirem em diversos níveis de experiência, aproximando autor e espectador cada vez mais confluentes no espaço digital. Sob a ótica de Walter Benjamin e de Vilém Flusser são consideradas as transformações advindas da técnica, interferindo no conceito de identidade e cultura no mundo contemporâneo.

Palavras-chave:

Arte, experiência e imagem virtual 


\title{
Image and experience
}

\author{
BEATRIZ ROCHA LAGOA
}

\section{Abstract}

This article considers virtual images as capable to rebound levels of experience, approaching author and spectator, even more confluents in the digital space. From the

Keywords: Art, experience and virtual image perspective of Walter Benjamin and Vilém Flusser, technical transformations are considered, interfering on the concepts of identity and culture in the contemporary world. 
A informação no mundo contemporâneo confunde-se com identidade.

Desde a fusão da informática com a telecomunicação, a informação encontra-se cada vez mais integrada à tecnologia na nossa cultura, expandida em um espaço de comunicação simultânea, cujo acesso ocorre através de dispositivos portáteis que prescindem das especificidades de tempo ou lugar. $\mathrm{O}$ indivíduo neste contexto se vê transformado em um "eu" coletivo, de acordo com os vários pontos de vista favorecidos pela colaboração.

Dados novos foram introduzidos com a informática, tais como os programas (softwares) e as interfaces (mouses, teclados, monitores, etc.), interpondo-se entre o computador (hardware) e o usuário. Estes elementos intermediários é que permitem as trocas de informação através de imagens matematicamente construídas, reprodutíveis e manipuláveis. Por sua vez, são as imagens mediadas, expandindo a visão, a audição e o tato, que interferem nos processos de percepção individual, bem como nos sistemas de organização social, político e cultural de todo o planeta.

Desde o surgimento do hipertexto world wide web, estruturando a informação no ambiente computacional, qualquer pessoa está autorizada a navegar, construir sites ou possuir contas de correio eletrônico. Redes sociais - twitter, facebook, etc. - e sites, como o youtube, batem recordes de acessos e trocas, caracterizando o computador como um espaço de comunicação navegável, centrado em fluxos de informação. Nele, indivíduos, ou grupos, trocam experiências e conhecimentos que podem ser armazenados e consultados a todo instante, gerando uma incrível quantidade de informação. Por sua vez, a informação demanda a atualização de uma tecnologia que garanta a qualidade, a leveza e o espaço necessários para armazenamento e troca de arquivos ininterruptamente. 
Se todo ato registrável é passível de virar informação, concluímos que o sistema computacional não configura apenas um instrumento de produção e comunicação de imagens, desenhos, textos ou sons sobre suportes fixáveis: ele também assume o papel de produtor de experiências, traduzido em manifestações sensíveis que dependem da demanda do usuário. Dentre elas, a principal experiência midiática remete à possibilidade de intervir na informação através das ferramentas computacionais e, consequentemente, construir significados de modo interativo.

Várias questões se colocam, nos tempos atuais, ao lidar com esses excessos. Por exemplo, quais serão os limites corporais impostos para processamento e memória? Quais os efeitos dessas informações, codificadas em imagens, exigindo interação constante? Como selecionar ou fazer escolhas, ou por outra, como evitar a dispersão no contexto informacional? Qual o papel dos mundos criados pela tecnologia? Eles preenchem, através do entretenimento, o vazio que a sociedade proporciona em termos de comunicação intersubjetiva?

Sob o ponto de vista histórico, os meios de comunicação portadores de informação desenvolveram-se em uma cultura de massa, tentando refazer os laços dos indivíduos atomizados, reclusos em espaços privados, com a sociedade dominada pelo consumo. Mas na cultural digital, ainda se aplica o conceito de massa? Ou ela estará sendo substituída pela noção de individualização?

Certamente não podemos negar a ambivalência de estarmos sós diante da tela do computador, ou demais dispositivos, e ao mesmo tempo conectados a milhões em rede. Se no contexto digital o isolamento não gera autoconhecimento, a integração no todo exige uma troca constante que fragiliza a opinião. Paradoxalmente, ter opinião é condição necessária para fazer parte do universo de quem usufrui da informação. Então, como se produz a noção de identidade? Será ela resultante de fragmentos recompostos apenas no nível superficial da experiência?

Talvez o maior problema, ao lidar com os excessos de comunicação, seja justamente a perda da capacidade de reflexão, necessária para percebermos aquilo que realmente interessa e nos afeta, evitando assim a banalização da informação. Para isso será necessário ultrapassar, nas redes da Internet, a expressão de uma vivência duvidosa, em consequência da versão editada de nós mesmos em circulação, deixando transparecer de modo parcial os sentimentos, as percepções ou os 
saberes que cada vez mais atendem à urgência de um intenso compartilhamento.

\section{Estética e reprodutibilidade}

Um mergulho na leitura de alguns textos do crítico Walter Benjamin nos fará perceber a atualidade do seu pensamento, em se tratando das mutações tecnológicas vivenciadas no nosso dia a dia. Ao tratar da noção de experiência, Benjamin já havia previsto perdas nos excessos de informação, contribuindo para tornar os indivíduos cada vez mais solitários. No texto O Narrador (BENJAMIM, 1938), o autor contrapõe a experiência perdida a uma vivência plena de eventos e sensações, necessária para reagir a uma espécie de embotamento, resultante da leitura de informações fragmentadas e desconexas veiculadas nos jornais. Só a partir dessa vivência seria possível obter recursos direcionados às experimentações estéticas, ou poéticas, que atingiriam no leitor um nível mais elevado de afecção.

No caso, Benjamin aponta claramente a importância da qualidade no contexto da informação, atribuída à experiência estética. Ele reforça a ideia de que só a arte, resultante da técnica, da linguagem e da ética, seria capaz de produzir experiências em níveis profundos de subjetividade, potencializando um modo de sentir compartilhável que repercute em situações ainda por vir.

Em um dos seus ensaios mais famosos, $A$ obra de arte na era da sua reprodutibilidade técnica, de 1936, Benjamin ocupa-se mais especificamente da experiência estética, indicando mudanças conceituais que assinalariam a destruição da velha forma (aura) em uma nova forma (reprodução). O que está em questão no texto é a transformação do componente físico da obra de arte, bem como a alteração da relação entre produtor e receptor, todos repercutindo na cultura.

Quando trata da reprodutibilidade técnica, Benjamin atribui uma estética ao cinema, ao rádio e à fotografia, sem questionar a natureza artística destes meios. De acordo com seu pensamento, o cinema seria o grande responsável pela mudança no processo receptivo vigente, ao provocar uma sensação de realidade em função da narrativa em movimento projetada na tela.

Apesar de não existirem imagens digitais na época em que Benjamin escreveu este texto, podemos atribuir a elas carac- 
terísticas pertinentes ao filme cinematográfico, tanto sob o ponto de vista do criador - que lida com um modo disperso e fragmentado de perceber uma realidade passível de ser reunificada no processo de montagem - quanto na relação com o espectador, multiplicado em muitos, que agora se percebe vendo e sendo visto na narrativa do filme. Fato que determina uma mudança de postura mais participativa do que aquela que ocorria com as formas artísticas anteriores.

Como nos faz crer Benjamin, se as formas apesar de mortificadas estão presentes em germe umas nas outras, como é o caso da pintura representativa presente na fotografia, ou da fotografia presente no filme que lhe acrescenta movimento, a imagem digital acrescentaria ao filme e à fotografia a capacidade de transformação. Com a perda de um original, ainda existente na película cinematográfica e no negativo fotográfico, as imagens digitais podem hoje ser copiadas, animadas, modificadas, filtradas, reconstituídas, combinadas ou inseridas em documentos e projetos, fazendo do receptor, com suas pulsões e emoções latentes, um cocriador no ambiente computacional.

Na verdade, a proposta de atuação do espectador no processo criativo não é nova, uma vez que a persistência de uma dimensão subjetiva, contrapondo-se à estética normativa, eterna e universal, desafia a figura do autor ao longo do século XX. Essa atuação acentua o caráter de "obra aberta" (1988), sem contornos nítidos, em favor da interdisciplinaridade e da recepção expandida do processo criativo.

Ainda em Benjamin, no texto Pequena História da Fotografia (1994), é interessante verificar como ele trata do conceito de "inconsciente óptico", expondo outro real na fotografia, graças aos recursos como o da câmera lenta e o da ampliação que ultrapassam a esfera consciente do visível. Ao afirmar, a partir dos recursos da técnica, o registro daquilo que não é percebido normalmente, Benjamin também aponta o alcance e a natureza imaginativa das nossas percepções, atraindo além das experiências palpáveis as memórias, os jogos e as simulações que são próprias do nosso corpo pensante.

\section{Dialética da imagem}

Mesmo que a hipótese do progresso técnico compreendido como forma de revolucionar a arte seja fato consumado, conjetura-se que uma das maiores transformações nos dias de hoje decorra da substituição da reprodutibilidade pelas novas reali- 
dades dos jogos e atividades digitais, aptos a gerar experiências estéticas a partir dos meios técnicos (MACHADO, 2007). Pois é a inserção do jogador nas imagens digitais que aguça o surgimento das experiências plenas de emoções que se equiparam (superam?) àquelas existentes no mundo fora da tela.

Apesar de restrito ao ambiente digital e centrado em apenas um ponto de vista, o jogador se vê imerso em situações simuladas pelos códigos digitais, transportando-se a espaços que autorizam o exercício de uma vivência criativa, impulsionada pela imaginação. Mas até que ponto o exercício da imersão substitui o contato vivo, ou de que maneira o comportamento restrito à tela define alterações comportamentais e físico-químicas no cérebro, estas são questões atuais e pertinentes aos debates de diversas áreas de estudo, principalmente os relativos à Psicologia Social e à Neurolinguística.

Já que é impossível negar que habitamos uma cultura dominada pelas imagens, presentes nas fotos, nos vídeos, nos filmes, na TV ou no computador, todas carregadas de informações que ora remetem aos apelos consumistas, ora à socialização ou à diversão, consideramos cada vez mais estas imagens próximas do mundo real, revelando um potencial estético responsável por opções de percepção, interação e design de interface. Uma estética na melhor das hipóteses capaz de interferir politicamente de forma crítica, ou por outra, apta a manipular consciências e condutas de toda ordem.

Mas como vimos anteriormente, de acordo com o pensamento de Benjamin existiria algo nas imagens que não pode ser apreendido de todo, sugerindo uma irracionalidade que escapa à percepção humana. Essa característica ambígua das imagens é reforçada por Vilém Flusser (2008), que considera especificamente a imagem virtual sob o prisma de uma visibilidade que a torna concreta, sem descartar o fato de que ela também pode ser abstrata, pois foi gerada por meio de um código matemático. O paradoxo da imagem virtual assim demonstrado remete diretamente ao fato de que ela tanto pode ser vivenciada em nível físico, quanto estar presente em vários espaços simultâneos.

Tal como a imagem fotográfica, a imagem virtual esconde do usuário o processo tecnológico que a gerou, diz Flusser, sendo experimentada apenas pelos recursos sensíveis das interfaces que, no entanto, alteram a sua capacidade de interação. Ao definir a corporeidade das imagens virtuais, bem como a possível dificuldade de interação através das interfaces, Flusser antecipa a existência das imagens intuitivas, as 
quais eliminarão de uma vez por todas os vestígios dos dispositivos interpostos na relação com o espectador/participador.

O que aproxima os pensamentos de Flusser e o de Benjamin é o interesse pelas diferentes formas artísticas e a variação nas concepções estéticas, principalmente quando ambos tratam da experiência visual expandida para os demais sentidos do corpo. Como Benjamin, Flusser nos alerta para a possível alienação e diminuição intelectual, moral e estética dos indivíduos, ao reforçar o modo perverso como a força totalitária das imagens repercute nos aparelhos. Ele também não nos deixa esquecer, quando trata da superficialidade das imagens técnicas, que os meios exercem influência sobre a mensagem e sobre a futura experiência. Porém, as mídias em si nunca poderão ser estetizadas, pois são apenas instrumentos de manifestação artística, e não a sua finalidade.

\section{Participação interativa}

Os conceitos de aura, singularidade e originalidade não se aplicam mais às imagens digitais. Também não é válido, nos dias de hoje, pensar nos meios separados e independentes, visto que os suportes de expressão diluíram as fronteiras formais e materiais, ao permitir o intercâmbio entre filmes, fotos, vídeos, textos e mídias digitais, todos provenientes da mesma relação entre arte e tecnologia. Além do mais, a criação da estrutura do hipertexto transformou o computador em metamedium, rompendo com a unidade organizacional informativa e autorizando a circulação nas mídias interativas.

As mutações radicais que caracterizaram as tecnologias de comunicação no final do século XX foram responsáveis pela criação de uma nova forma digital que concilia ubiquidade, simultaneidade e distribuição massiva. Mas nessa mesma forma germinam os questionamentos que percorrem a arte desde o modernismo até a contemporaneidade, dentre eles a superação da noção de objeto e a alteração da relação autor/ espectador/obra, aproximando-se cada vez mais de aspectos do cotidiano.

Foi justamente no século passado que despontou um método de trabalho baseado na experimentação e nos avanços da ciência, permeando principalmente os manifestos e as obras dos artistas futuristas e construtivos. A partir desse momento a arte se viu direcionada para áreas antes restritas de modo exclusivo aos técnicos e engenheiros. Em destaque, nos anos 1920/30, a obra fílmica do cineasta Sergei Eisenstein, tratando da inten- 
sificação extrema das imagens em termos de plasticidade e movimento, visando arrebatar e transportar emocionalmente o espectador para o ambiente do filme projetado. $\mathrm{O}$ interesse pelos ideogramas define, nos filmes de Eisenstein, um processo de montagem que alia conceito e sensibilidade, impossíveis de serem separados nessa escrita e, consequentemente, na própria cultura chinesa (e japonesa) de onde ela é proveniente.

Ainda no período modernista, Dada e Surrealismo propõem uma experiência estética que questiona a visão contemplativa do espectador, ampliada na década de 1960 para as experiências interativas que reforçam um modo de arte processual e intermidiático. Incluem-se, nesta ocasião, as propostas que fazem do corpo o suporte da obra, atribuindo-lhe uma dimensão estética integrada ao processo criativo.

$\mathrm{O}$ interesse pela tecnologia, no início do século XX, atestando uma crença inabalável no progresso, adquire outra face em meados dos anos 1960, quando se expandem os meios de comunicação. Com a Pop, as fronteiras entre estética popular e erudita são diluídas, confrontando o espectador com a cultura de massa, a industrialização e a sociedade de consumo. Nas décadas subsequentes, vários artistas propõem experiências que utilizam as tecnologias da comunicação, inicialmente em meios não digitais (vídeo, TV, fax, etc.), para logo em seguida migrarem em direção aos meios digitais.

Quando o ambiente computacional passa a ser explorado como forma de expressão artística, na década de 1990, reformulam-se os parâmetros de tempo e espaço existente nas artes participativas anteriores. Pois é justamente a imaterialidade dos projetos que provoca a relação de ubiquidade, desembocando na criação coletiva e intersubjetiva dos dias atuais.

A arte virtual configura um novo potencial estético que aproxima as funções do artista e do designer, ambos às voltas com o manejo das ferramentas geradas pelos softwares nos computadores (MANVICH, 2008). A interação profunda entre método de trabalho e as diferentes mídias é que permite indagar sobre a possibilidade de uma nova estética, como propõe o teórico Lev Manovich (2002), afirmando a possibilidade de alterações cognitivas e afetivas, inspiradas no modo de operação fragmentado pelo impulso dos comandos dos programas.

No entanto, o trabalho artístico realizado com os softwares considera algumas restrições, dentre elas o próprio ambiente que impõe os seus limites. Em última análise ainda é a ideia de projeto, transposto passo a passo, que baliza a criação no espaço virtual. Em destaque a possibilidade da modifica- 
ção independente de cada elemento da imagem, do texto ou da música, desde a concepção do projeto até o produto final, também modificável no processo de elaboração da obra.

\section{Referências}

BENJAMIN, Walter. A obra de arte na era da reprodutibilidade técnica, 1936. In: Magia e técnica, arte e política. Ensaios sobre literatura e história da cultura. Volume 1. São Paulo: Brasiliense, 1987.

BENJAMIN, Walter. O Narrador. Considerações sobre a obra de Nicolai Leskov, 1934. In: Magia e técnica, arte e política. Ensaios sobre literatura e história da cultura. Volume 1. São Paulo: Brasiliense, 1987.

BENJAMIN, Walter. Pequena História da Fotografia, 1931. In: Magia e técnica, arte e política. São Paulo: Brasiliense, 1994. ECO, Umberto. Obra Aberta. Forma e indeterminação nas poéticas contemporâneas. São Paulo: Perspectiva, 1988.

FLUSSER, Vilém. O universo das imagens técnicas. Elogio da superficialidade. São Paulo: Annablume, 2008.

MACHADO, Arlindo. Arte e Mídia. Rio de Janeiro: Zahar, 2007.

MANOVICH, Lev. Software takes command., 2008. Disponível em <softwarestudies.com/softbook>. Acesso em 10.01.2012.

MANOVICH, Lev. The language of new media. Cambridge: Mit Press, 2002.

Recebido em: 05/01/12

Aceito em: 05/01/12 


\section{BEATRIZ ROCHA LAGOA}

b-lagoa@hotmail.com

É professora adjunta na Escola de Comunicação da UFRJ, onde desenvolve pesquisa de pós-doutoramento na área de Estudos Culturais / Novas Tecnologias, junto ao PACC-UFRJ. Possui doutorado em História Social da Cultura (PUC-Rio) e mestrado em História da Arte (EBA-UFRJ). Graduou-se em Comunicação Visual e Desenho Industrial pela PUC-Rio e, desde então, desenvolve e coordena projetos de criação gráfica e redação. Publica textos em revistas acadêmicas de arte e de cultura. 